\title{
PENGEMBANGAN KECERDASAN SPIRITUAL PADA PESERTA DIDIK MELALUI AKTIVITAS KEAGAMAAN
}

\author{
Siti Qoni'ah \\ E-mail: sitiqoniah95@gmail.com \\ Institut Agama Islam Al-Khairat Pamekasan Madura
}

\begin{abstract}
The effort of the formation or establishment of spiritual intelligence on the students is done by planting Islamic religious values in PAI learning and character planting which then implemented in the form of daily behavior that reflects the character or identity of each individual learners and is supported by the religious program that have been compiled by the school institution.

This study aims to (1) Describe and analyze the process of the formation of spiritual intelligence on students or learners (2) Describe and analyze the implementation of religious activity programs in shaping spiritual intelligence in learners (3) Describe and analyze the impact of the formation of spiritual intelligence in learners through the implementation of the religious program.

This research uses qualitative research approach. The type of research used in this research is case study and case studies and multiple cases design. Data collection uses observation, interview and documentation.

The results showed that in SD Plus Nurul Hikmah the formation of spiritual intelligence is done by planting the values of faith and pillars of Islam as well as the implanting of characters in learning PAI and applied through the program of religious activity and application of character, while in MIN Konang the formation of spiritual intelligence done by planting The prophet characteristics and the prophet's story in learning PAI as well as the planting of characters applied in the form of religious activity and the application of character.

The formation of spiritual intelligence in both schools can be concluded that overall spiritual intelligence in learners has been formed, it is known from attitudes, behaviors and religious activities always performed by learners at both school and at home, although the results have not reached one hundred percent, But both school is always working in terms of improving the strategy of the formation of spiritual intelligence in learners.
\end{abstract}

Keywords: The formation or establishment of spiritual intelligence in learners, Religious Activity

MODELING: Jurnal Program Studi PGMI

Volume 6, Nomor 2, September 2019; p-ISSN: 2442-3661; e-ISSN: 2477-667X, 159-175 


\title{
Pengembangan Kecerdasan Spiritual
}

\begin{abstract}
Abstrak
Kecerdasan spiritual merupakan kecerdasan untuk menempatkan perilaku dan hidup seseorang dalam makna yang lebih luas dan kaya, yaitu penggabungan antara kecerdasan emosional dan nilai-nilai spiritual, kecerdasan ini dapat di wujudkan melalui keagamaan, yakni aktivitas yang diantaranya berdoa, membaca al-Qur'an, sholat berjamaah, berdzikir dan bersholawat. Penelitian ini bertujuan untuk mendeskripsikan dan menganalisis proses pengembangan kecerdasan spiritual pada peserta didik, pelaksanaan program aktivitas keagamaan dalam mengembangkan kecerdasan spiritual pada peserta didik serta mendeskripsikan dan menganalisis dampak pengembangan kecerdasan spiritual pada peserta didik melalui pelaksanaan program aktivitas keagamaan. Penelitian ini menggunakan pendekatan penelitian kualitatif, jenis penelitian yang digunakan adalah studi kasus (case studies) dan rancangan multi kasus, pengumpulan data menggunakan observasi, wawancara dan dokumentasi. Hasil penelitian menunjukkan bahwa di SD Plus Nurul Hikmah proses pengembangan kecerdasan spiritual dilakukan dengan cara penanaman rukun iman dan rukun islam serta penerapan karakter. pelaksanaan rukun iman dan rukun islam kedalam bentuk aktivitas keagamaan dalam mengembangkan kecerdasan spiritual pada peserta didik yang meliputi berdoa sebelum kegiatan belajar dimulai, membaca al-qur'an dan sholat berjamaah. Dampak aktivitas keagamaan terhadap pengembangan kecerdasan spiritual pada peserta didik dapat dilihat dari tingkah laku mereka yang mencerminkan sikap religius, disiplin, jujur dan tanggung jawab. Sedangkan di MIN Konang menunjukkan bahwa proses pengembangan kecerdasan spiritual dilakukan dengan cara penanaman sifat-sifat rasul dan penerapan karakter. pelaksanaan sifat-sifat rasul dilaksanakan melalui bentuk perilaku diantaranya bertanggung jawab dalam segala aktivitasnya di sekolah sehingga peserta didik akan dipercaya oleh guru dalam menjalankan tugas dan kewajibannya termasuk kewajiban dan kesadarannya dalam menjalankan program aktivitas kegamaan yang meliputi berdoa, membaca al-qur'an, berdzikir. Dampak aktivitas keagamaan berupa sikap yang disiplin, bertanggung jawab, jujur, sopan santun dan religius.
\end{abstract}

Kata kunci: kecerdasan Spiritual, Aktivitas Keagamaa

\section{PENDAHULUAN}

Kecerdasan Spiritual merupakan kemampuan yang dimiliki manusia dalam memaknai setiap persoalan dalam kehidupan dengan menggunakan pendekatan agama dan menjadi kebutuhan setiap manusia di era globalisasi. ${ }^{1}$ banyak orang tua

\footnotetext{
${ }^{1}$ Ari Ginanjar, Rahasia Sukses Membangun Kecerdasan Emosi dan Spiritual, (Jakarta: Arga Tilanta, 2003), hlm. 95
} 
yang tanpa sadar telah melakukan proses pendidikan yang mendorong anak untuk mencapai kesuksesan materi, popularitas dan menyisihkan nilai-nilai spiritualitas anak. Akibatnya adalah anak hanya memikirkan bagaimana dia mencapai keinginannya dengan cara apapun, serta hanya mementingkan egoisme semata. ${ }^{2}$ Ketiadaan keceredasan ruhaniah atau spiritualitas telah mengakibatkan hilangnya ketenangan batin dan pada akhirnya mengakibatkan hilangnya kebahagiaan pada diri anak tersebut.

Kecerdasan spiritual akan membantu seseorang untuk mengatasi masalah kehidupan yang tidak dapat diselesaikan oleh kecerdasan manusia lainnya seperti Kecerdasan intelektual (IQ) ataupun Kecerdasan emosional (EQ). Keduanya cenderung bersifat meterial dan tidak mampu menangkap sesuatu yang bersifat transenden. Dengan kecerdasan spiritual seseorang tidak hanya memecahkan persoalan hidup secara rasional atau emosi saja, tetapi ia juga mampu menghubungkannya dengan makna kehidupan secara spiritual. ${ }^{3}$

Realitas pendidikan di era globalisasi yang mengabaikan nilai-nilai spiritual telah mengakibatkan hilangnya arah dan tujuan pendidikan itu sendiri yaitu mencetak manusia yang paripurna (Insan Kamil). Pendidikan saat ini banyak terjebak dalam arus modernisasi yang lebih mengedepankan corak hedonisme dan apatisme (acuh tak acuh, tak peduli). ${ }^{4}$

Di antara masalah yang timbul akibat krisis spiritual dalam pendidikan pada pelajar di era globalisasi ini, pertama, tidak henti-hentinya kita mendengar berita tentang tindakan kriminalitas yang dilakukan oleh anak-anak, seperti yang terjadi di beberapa daerah yang hampir setiap minggu diberitakan di berbagai media cetak maupun elektronik. Bagi sebagian daerah bukan suatu hal yang aneh apabila mendengar atau melihat anak-anak sekolah melakukan tawuran (perkelahian antar pelajar) yang tidak sedikit menimbulkan sejumlah korban. ${ }^{5}$ Sebagaimana diungkapkan oleh seorang pemerhati anak Seto Mulyadi, yang menanggapi kasus tawuran antar pelajar, bahwa perlu adanya pendidikan spiritual bagi para siswa guna mencegah timbulnya kembali tawuran dikalangan pelajar. Seto menilai pendidikan spiritual pada anak kini mulai terlupakan, baik oleh guru maupun orang tua. hal inilah yang membuat siswa kurang memiliki sikap keteladanan. Siswa hanya ditekankan pada prestasi dalam bentuk ranking dan nilai bagus tanpa disertai pendidikan spiritual. Padahal menurutnya pendidikan spiritual mampu membentuk kepribadian siswa untuk menjahui hal-hal negatif, termasuk tawuran. ${ }^{6}$ Kedua, jika melihat data hasil survey dari KPAI yang menyatakan bahwa $32 \%$ pelajar indonesia

\footnotetext{
${ }^{2}$ Safaria, Kecerdasan Spiritual, (Jakarta: Media Pustaka, 2007), hlm. 11-12.

3 http://www. Rahmat muthahhari.or.id/doc/artikel/sqanak.htm). dikutip kamis, 5 Januari, 2017.

${ }^{4}$ Abuddin Nata, Metodologi Studi Islam, (Jakarta: PT. Raja Grafindo Persada, 2012), hlm. 30

${ }^{5}$ Rahayu, Dita. Artikel, Krisis Moral, 2015.http://www.kompasiana.com.dikutip, Kamis,5 September 2016.

${ }^{6}$ Rahmawati, Ulfah. Jurnal, pentingnya kecerdasan spiritual pada anak, 2016. http://www.jurnal pendidikan.com. dikutip, Rabu, 4 Juli 2016.
} 


\section{Pengembangan Kecerdasan Spiritual}

pernah melakukan perbuatan asusila, pelecehan seksual dan melakukan hubungan seks diluar nikah. Tentunya ini sudah cukup menjadi bukti ketidakefektifan penerapan sistem pendidikan kita saat ini. ${ }^{7}$

Dari berbagai masalah tersebut, menimbulkan suatu kekhawatiran bagi para orang tua terhadap masa depan anak-anak mereka. Para orang tua khawatir anaknya akan terpengaruh oleh budaya-budaya negatif yang sedang menjamur di kalangan anak-anak dan remaja seperti yang telah disebutkan di atas. Dampak globalisasi tersebut tidak dapat dicegah, namun sebagai bangsa Indonesia yang bijaksana sebaiknya dilakukan upaya cerdas untuk menanggulangi bahaya dampak-dampak negatif globalisasi. Upaya yang tepat untuk menanggulangi dampak negatif tersebut yaitu melalui ranah pendidikan.

Pendidikan yang tepat dalam mengembangkan kecerdasan spiritual pada anak, harus mencangkup proses pembentukan kecerdasan spiritual agar potensi kecerdasan spiritual yang merupakan fitrah anak sejak lahir akan terasah dan dapat dikembangkan dengan baik dan juga didukung dengan program-program aktivitas keagamaan. Proses pembentukan kecerdasan spiritual di lingkungan pendidikan sekolah dasar diawali dengan dasar penanaman ketauhidan, pemahaman Asmaul Husna, mengimani dan mengaplikasikan nilai-nilai yang terkandung dalam ajaran pendidikan agama Islam.

Ketika zaman terus berkembang, maka orang tua pun semakin dituntut untuk menjadi orang tua masa kini yang harus memiliki strategi khusus bagi masa depan anak-anaknya. penting bagi orang tua untuk merencanakan pendidikan anaknya. Orang tua tidak hanya bertanggung jawab atas pendidikan dalam keluarga, akan tetapi orang tua juga bertanggung jawab atas pendidikan di luar keluarga, yaitu dengan memilih sekolah yang tepat untuk mengembangkan segala potensi yang dimiliki anak sehingga memiliki masa depan yang lebih baik. Para orang tua yang khawatir akan dampak-dampak negatif perkembangan zaman berusaha mencari solusi melalui lembaga pendidikan yang dianggap mampu mengatasi berbagai permasalahan yang membuat mereka risau. Orang tua harus selektif dalam memilih sekolah untuk putra-putrinya.

Memilih sekolah yang tepat membutuhkan banyak pertimbangan, mulai dari lingkungan sekolah, kurikulum yang digunakan, kondisi sarana dan prasarana yang ada, sampai pada kegiatan harian yang dilaksanakan dalam sekolah. sekolah Islam terpadu dan sekolah madrasah ibtidaiyah dapat menjadi salah satu alternatif pilihan orang tua dalam menentukan lembaga pendidikan yang tepat bagi anak dalam mengajarkan pendidikan nilai-nilai agama yang nantinya akan bermanfaat bagi kehidupan anak di masa depan untuk membekali hidupnya dengan nilai-nilai agama dan untuk mengembangkan potensi kecerdasan spiritual anak.

Sekolah dasar Islam atau madrasah ibtidaiyah merupakan lembaga pendidikan islam sebagai upaya tahap dasar awal pembentukan karakter religius pada jiwa anak,

${ }^{7}$ Badan Pusat Statistik, http://www.tribunjabar.co.id/read/artikel. dikutip Kamis, 5 Desember 2016.

MODELING, Volume 6, Nomor 2, September 2019 | 162 
setelah anak mendapat nilai religius dalam lingkungan keluarganya ketika masih balita kemudian dilanjutkan pada lingkungan sekolah dasar yang dimulai dari anak berusia 6-12 tahun, ini adalah usia awal atau dasar anak yang tepat untuk langkah awal dalam membentuk jiwa anak yang mempunyai akidah dan pengetahuan dasar agama. Pendidikan agama islam yang diajarkan di sekolah dasar islam atau madrasah ibtidaiyah bertujuan untuk mengajarkan, melestarikan ajaran dan nilai-nilai islam, mengembangkan nilai-nilai etik religius, juga mengembangkan nilai-nilai hidup yang berupa nilai-nilai sosial atau persaudaraan. ${ }^{8}$

Penyelenggaraan Sekolah Dasar Islam dan Madrasah Ibtidaiyah dimaksud untuk menghasilkan lulusan yang mempunyai dasar-dasar karakter, kecakapan, keterampilan, dan pengetahuan yang memadai untuk mengembangkan potensi dirinya secara optimal sehingga memiliki ketahanan dan keberhasilan dalam pendidikan lanjutan atau dalam kehidupan yang selalu berubah sesuai dengan perkembangan iman.

Kecerdasan spiritual (SQ) dapat dilatihkan kepada anak sejak dini dengan langkah awal menanamkan kepada peserta didik tentang manfaat aktivitas keagamaan di sekolah yang kemudian dalam hati mereka tertanam nila-nilai spiritual yang kemudian dengan nilai-nilai spiritual tersebut mereka sadar pentingnya akan pelaksanaan aktivitas keagamaan di sekolah dengan begitu anak akan terbentuk sikap pembiasaan dan latihan yang merupakan salah satu sarana dalam upaya menumbuhkan keimanan anak, pembiasaan aktivitas keagamaan yang dimaksud diantaranya pembiasaan berdoa sebelum pelajaran dimulai dan ketika selesai kegiatan belajar, do'a menjadi bukti benarnya tawakkal seseorang kepada Allah Ta'ala. Karena ketika seseorang berdo'a berarti manusia menyerahkan semua urusannya kepada Allah semata tidak pada selain-Nya dan juga melalui berdoa akan mendekatkan manusia dengan Allah, sesuai dengan firman Allah dalam surat AlBaqarah ayat 186 yang menjelaskan bahwa sesungguhnya Allah itu sangat dekat dengan manusia jika manusia berkemauan untuk mendekatkan diri kepada Nya dengan jalan melalui berdoa kepada Allah. ${ }^{9}$

Kecerdasan intelektual melahirkan manusia yang mempunyai pola pikir dan cara pandang yang cerdas, tetapi sikap, perilaku dan pola hidupnya sangat kontras dengan kemampuan intelektualnya. Banyak orang yang cerdas secara akademik tetapi gagal dalam pekerjaan sosialnya. ${ }^{10}$ Mereka memiliki kepribadian yang berbeda sehingga tidak terjadi integrasi antara otak dan hati, fenomena tersebut telah menyadarkan para pakar bahwa kesuksesan seseorang tidak hanya ditentukan oleh kemampuan otak dan daya pikir semata, tetapi juga di pengaruhi oleh kecerdasan emosional dan kecerdasan spiritual.

\footnotetext{
${ }^{8}$ Muhaimin, Pengembangan Kurikulum Pendidikan Agama Islam, (Jakarta: PT. Raja Grafindo Persada, 2005), hlm. 76

${ }^{9}$ Departemen Agama RI, Al-Qur'an dan terjemahannya, (Jakarta: Kallam Mulia, 2000), hlm 70

${ }^{10}$ Abd Wahab, Kepemimpinan Pendidikan dan Kecerdasan Spiritual, (Jakarta: Ar-Ruzz Media, 29)
} 
Peneliti memperoleh informasi bahwa ada beberapa sekolah di Pamekasan Madura yang pembelajaran nilai-nilai agama islam nya bagus. Hal tersebut dilihat dari proses pengembangan kecerdasan spiritual dan program aktivitas keagamaannya. Sekolah tersebut ialah SD Plus Nurul Hikmah dan MIN Konang Galis Pamekasan. Peneliti mengadakan survei langsung kesekolahan tersebut dan kemudian peneliti melakukan dialog dan diskusi dengan pendidik dan kepala sekolah sebagai upaya menggali secara mendalam tentang proses pengembangan kecerdasan spiritual dan program-program aktivitas keagamaan yang mendukung pengembangan kecerdasan spiritual pada peserta didik. Hasil diskusi dan dialog pada tanggal 13 dan 14 Desember 2016 tersebut diperoleh beberapa gambaran sebagai berikut. SD Plus Nurul Hikmah Pamekasan memiliki visi untuk mewujudkan siswa bertakwa, beriman serta berprestasi. Proses pengembangan kecerdasan spiritual dilakukan dengan cara pengaplikasian rukun iman dan rukun islam ke dalam bentuk kegiatan keagamaan di sekolah seperti beriman kepada Allah dilakukan dengan cara senantiasa berdzikir sesudah shalat karena dengan berdzikir maka akan mengingat Allah dan dekat kepadaNya dan penanaman karakter yang baik seperti karakter religius, jujur, tolong menolong, rendah hati, displin dan tanggung jawab dan melalui program-program aktivitas kegamaannya.

Sedangkan proses pengembangan kecerdasan spiritual di MIN Konang Galis Pamekasan dilakukan dengan cara peneladan kisah rasul dan sifat-sifatnya diharapkan peserta didik mampu meneladani para rasul dan nabi yang sennatiasa taat dalam menjalankan syariat agama serta melalui penanaman karakter religius, jujur, rendah hati, disiplin, tanggung jawab,sopan dan santun.

Berdasarkan latar belakang yang telah dipaparkan di atas, peneliti sangat tertarik untuk mendeskripsikan fakta tersebut dan mengadakan penelitian yang berjudul " Pengembangan Kecerdasan Spiritual Pada Peserta Didik Melalui Aktivitas Keagamaan (Studi Multi Kasus di SD Plus Nurul Hikmah Pamekasan dan MIN Konang Galis Pamekasan."

\section{METODE PENELITIAN}

Penelitian ini menggunakan pendekatan kualitatif, dengan tujuan untuk mendapatkan gambaran tentang pengembangan kecerdasan spiritual melalui aktivitas keagamaan. Adapun jenis penelitian yang digunakan adalah studi kasus (case studies) dan rancangan multi kasus, dikarenakan dalam penelitian ini mengungkap dua kasus yang memiliki karakteristik yang berbeda dengan fokus penelitian yang sama yaitu tentang pengembangan kecerdasan spiritual pada peserta didik melalui aktivitas keagamaan di SD Plus Nurul Hikmah Pamekasan dan MIN Konang Galis Pamekasan. Perilaku yang terjadi di lapangan berupa kegiatan aktivitas keagamaan di SD Plus Nurul Hikmah Pamekasan dan MIN Konang Galis Pamekasan. Data dalam penelitian ini diperoleh melalui teknik wawancara, observasi, dan dokumentasi. Sumber data dari penelitian ini terbagi menjadi dua hal, yaitu meliputi data yang bersifat primer dan sekunder. Sumber data primer dalam penelitian ini adalah hasil dari wawancara 
dengan informan diantaranya adalah kepala sekolah, guru mata pelajaran Pendidikan Agama Islam, orang tua peserta didik, peserta didik. Sedangkan sumber data sekundernya berupa dokumen seperti : data aktivitas keagamaan, data perangkat pembelajaran, buku penghubung antara wali murid dengan sekolah atau buku prestasi ibadah peserta didik dan data dokumentasi foto aktivitas keagamaan.

\section{TEMUAN}

Temuan-temuan penelitian ini berdasarkan dari hasil penelitian yang peneliti lakukan di SD Plus Nurul Hikmah Pamekasan dan MIN Konang Galis Pamekasan. Jadi, pada bagian ini akan dipaparkan poin-poin penting dari hasil penelitian, adapun hasil temuan penelitian tersebut adalah:

Temuan Penelitian Pada Kasus I SD Plus Nurul Hikmah Pamekasan

a. Proses Pengembangan Kecerdasan Spiritual

Di SD Plus Nurul Hikmah pengembangan kecerdasan spiritual di dalam pembelajaran dilakukan dengan cara menanamkan nilai-nilai yang ada dalam rukun iman dan rukun islam di pembelajaran PAI, yang terdiri dari Beriman kepada Allah, iman kepada malaikat, iman kepada kitab-kitab Allah, iman kepada Rasul dan iman kepada hari akhir, iman kepada Qadha dan Qadar dan juga rukun islam yaitu syahadat, shalat, puasa, zakat dan haji. Materi tersebut betul-betul ditanamkan pengertiannya dalam pembelajaran karena merupakan pondasi dasar dalam pembentukan kecerdasan spiritual peserta didik . Kemudian guru mengaitkan dengan contoh kehidupan sehari-hari dan diterapkan melalui tindakan seperti berakhlak terpuji atau mempunyai karakter sikap yang baik, tutur kata yang sopan, serta penerapan program kegiatan aktivitas keagamaan yang berdasarkan pedoman dari nilai-nilai agama dan nilai-nilai rukun iman dan rukun islam.

b. Pelaksanaan Pengembangan Kecerdasan Spiritual

di SD Plus Nurul Hikmah bentuk-bentuk program keagaman dan waktu pelaksanaannya sebagai berikut :

1) Program ekstrakurikuler keagamaan

a. Berlatih membaca Al-Quran dengan tajwid yang benar, membaca al-Qur'an dengan tajwid yang benar akan mendapat banyak pahala, pihak sekolah melatih anak membaca al-Qur'an dengan menggunakan metode ummi dengan tujuan anak dapat membaca al-Qur'an dengan benar dan fasih serta diharapkan bisa menjadi Qori'. Ekstra ini diadakan setiap hari jumat pukul 14.00 WIB dan diikuti oleh peserta didik yang mempunyai minat dalam memperbaiki baca al-Quran nya.

b. Berpidato bahasa rab, kegiatan berlatih pidato bahasa Arab bertujuan untuk mengembangkan kemampuan bahasa arab peserta didik dan agar mereka lebih berani tampil di depan umum, dilaksanakan setiap hari jumat pukul 15.00 WIB dan diikuti oleh peserta didik yang ingin mengembangkan potensi bahasa arabnya.

165 | MODELING, Volume 6, Nomor 2, September 2019 
c. Nasyid, kegiatan ini melatih anak untuk bershalawat dengan diiringi musik dari mulutnya sehingga akan menimbulkan kreatifitas peserta didik dalam hal seni musik, ekstra ini dilaksanakan pada hari sabtu pukul 13.00 WIB.

d. Pelatihan Muhadharoh yang bertujuan untuk melatih anak untuk latihan berpidato atau ceramah menggunakan bahasa indonesia. Kegiatan ini bertujuan agar anak lebih percaya diri dan berani menyampaikan ilmunya di depan umum istilahnya menjadi dai kecil, ekstra ini dilaksanakan pada hari sabtu pukul 14.30 WIB.

2) Bentuk aktivitas keagamaan di SD Plus Nurul Hikmah

Berdasarkan pengamatan dan observasi yang peneliti lakukan tentang bentuk aktivitas keagamaan di SD Plus Nurul Hikmah berupa :

a. Membaca Asmaul Husna sebelum masuk kelas

Sebelum masuk ke dalam kelas peserta didik berbaris rapi didepan kelas nya masing-masing kemudian mereka membaca asmaul husna yang dipandu oleh wali kelas masing-masing. hal ini bertujuan agar tingkat keiman dan ketakwaan peserta didik kepada Allah semakin bertambah dengan mengetahui nama-nama Allah beserta sifatnya.

b. Doa Bersama Sebelum Memulai dan Ketika Selesai Kegiatan Belajar Mengajar. Sebelum memulai kegiatan belajar mengajar setiap pagi peserta didik selalu berdoa bersama yang dipandu oleh ketua kelas, meskipun gurunya belum datang anak-anak sudah melaksanakan doa bersama. Begitu juga setelah melaksanakan kegiatan belajar mengajar peserta didik juga melaksanakan doa bersama. Agar ilmu yang didapatkan bisa bermanfaat.

c. Membaca Al-Qur'an 15 menit sebelum waktu belajar jam pertama dimulai.

Setelah berdoa bersama peserta didik langsung membaca Al-Qur'an 15 menit setiap pagi sebelum proses pembelajaran dimulai denagn dipandu oleh guru yang mengajar jam pertama di kelas masing-masing. Strategi ini dilakukan agar peserta didik lancar dan dan fasih dalam membaca Al-Qur'an.

d. Sholat berjamaah dhuha dan sholat berjamaah dzuhur dan ashar.

Sholat Dhuha dilaksanakan pada jam 10.00 WIB, waktu istirahat. dilaksanakan secara berjamaah dan manfaatnya dari sholat Dhuha sendiri memang sangat banyak dan tentu saja sangat bermanfaat untuk seseorang, selain untuk membukakan pintu rezeki agar lebih baik, sholat dhuha sendiri juga memiliki manfaat lain untuk kesehatan. Sedangkan shalat dzuhur dilaksanakan pada pukul 12.15 WIB dilaksanakan secara berjamaah juga begitu pun shalat ashar juga dilaksanakan secara berjamaah pada pukul 15.15 wib.

3) Dampak Pengembangan Kecerdasan Spiritual

Di SD Plus Nurul Hikmah Pamekasan perilaku peserta didik selama di sekolah, mereka menunjukkan sikap disiplin, jujur, sopan dan santun serta tanggung jawab sedangkan dampak pengembangan kecerdasan spiritual melalui aktivitas keagamaan selama di rumah diterapkan dalam bentuk karakter yang berupa konsisten dalam mengerjakan ibadah sholat, mengaji, berpuasa penuh bagi yang sudah baligh, 
mengerjakan pekerjaan rumah, mengerjakan pr di rumah dan patuh kepada orang tua namun masih terdapat sebgaian peserta didik yang bandel dalam melakukan kegiatan keagamaan selama di rumah, hal ini dikarenakan pengawasan dari orang tua di rumah kurang karena sibuk dengan pekerjaannya sendiri kemudian tugas pengawasan kegiatan anaknya selama di rumah mereka titipkan ke orang lain dan terkadang lupa mengisi laporan kegiatan keagamaan selama di rumah di dalam buku penghubung ibadah, solusinya adalah pihak sekolah senantiasa memberi motivasi agar orang tua senantiasa lebih memperhatikan kegiatan anaknya selama di rumah.

4) Kasus II MIN Konang Galis Pamekasan

a. Proses Pengembangan Kecerdasan Spiritual

Di MIN Konang Galis Pamekasan pengembangan kecerdasan spiritual di dalam pembelajaran dilakukan dengan cara menanamkan sifat-sifat rasul dan peneladanan kisah rasul dalam pembelajaran PAI. Dalam mata pelajaran Aqidah Akhlak dijelaskan tentang materi mengenal sifat-sifat wajib nabi dan rasul yang harus dicontoh oleh peserta didik dan diterapkan baik di sekolah maupun di rumah, materi tersebut dijelaskan secara berjenjang berdasarkan tingkat kelas masing-masing kemudian juga penjelasan kisah-kisah rasul dijelaskan pada mata pelajaran ski (Sejarah Kebudayaan Islam). Sedangkan pada mata pelajaran Fiqih terdapat materi tentang bab rukun Iman dan rukun Islam, guru mencontohkan bahwa Rasulullah selalu taat mengerjakan apa yang ada di rukun iman dan rukun Islam dengan menceritakan kisahnya, pada mata pelajaran al-Qur'an Hadis dijelaskan oleh guru dengan cara menceritakan jika rasulullah dulu selalu menghafal wahyu yang disampaikan oleh Allah kepadanya lewat malaikat Jilbril. Guru menyampaikan bahwa menghafal ayat-ayat Allah itu penting agar senantiasa ingat perintah Allah melalui ayat-ayat Nya dan juga mengahafal makna dari ayat Al-Qur'an. Peneladan sifat-sifat nabi melalui kisahnya betul-betul diterapkan oleh guru didalam pembelajaran dan nanntinya dapat diterapkan dalam kegaiatn seharihari baik disekolah maupun di rumah.

b. Pelaksanaan Pengembangan Kecerdasan Spiritual

Di MIN Konang Galis Pamekasan bentuk-bentuk program keagaman dan waktu pelaksanaannya sebagai berikut :

1) Program ekstrakurikuler keagamaan

Ekstra pelatihan berpidato bahasa arab dilaksanakan pada hari kamis pukul 15.00 wib, kegiatan ini bertujuan untuk melatih anak mengembangkan kemampuan bahasa arab yang mereka miliki, kemampuan mengembangkan kosa kata bahasa arab sehingga tersusun menjadi kalimat yang berupa teks; pidato, nasyid dilaksanakan pada hari sabtu pukul 14.33 wib yang bertujuan untuk melatih anak untuk bershalawat, tilawah dilaksanakan pada hari jumat pukul 14.00 wib yang bertujuan untuk melatih anak bagus dalam membaca al-quran dan 


\section{Pengembangan Kecerdasan Spiritual}

melagukannya dan pelatihan muhadaroh yaitu berlatih pidato atau ceramah dilaksanakan pada hari minggu pukul 13.00 wib di sekolahan.

2) Bentuk aktivitas keagamaan di MIN Konang Galis Pamekasan

Budaya bersalaman dengan guru didepan gerbang masuk sekolah (sebelum peserta didik masuk ke halaman sekolah), Membaca asmaul husna sebelum masuk kelas, membaca alquran 15 menit sebelum pembelajaran dimulai, berdoa sebelum dimulai pembelajaran dan sesudah pembelajaran, melaksanakan shalat berjamaah dhuhur yang dilaksanakan pada pukul 12.00 wib dan melaksanakan shalat dhuha pada pukul 10.22 wib (waktu istirahat), dan menyetor hafalan juz amma.

Penerapan perilaku yang berpedoman pada sifat -sifat rasul di rumah, dilakukan dengan cara selalu berbuat jujur kepada orang tua dan senantiasa melaksanakan perintah orang tua dengan penuh tanggung jawab.

c. Dampak Pengembangan Kecerdasan Spiritual

Dampak pengembangan kecerdasan spiritual pada peserta didik di MIN Konang sebagai berikut :

Rasa keimanan dan ketakwaan kepada Allah SWT semakin meningkat, peserta didik mempunyai sifat sopan, santun dan ramah, peserta didik mempunyai sifat disiplin dan menghargai waktu serta memiliki rasa tanggung jawab, peserta didik memiliki rasa empati dan tolong menolong, peserta didik mempunyai sifat kejujuran dan rendah hati, peserta didik dapat membagi waktunya secara seimbang dan memiliki perilaku dan budi pekerti yang luhur.

Sedangkan dampak pengembangan kecerdasan spiritual pada peserta didik di rumah sebagai berikut :

Mempunyai sikap Sopan, santun dan ramah, keimanan dan ketakwaan peserta didik meningkat, mempunyai sikap disiplin dan rasa tanggung jawab dan mempunyai sikap tolong menolong.

\section{HASIL DAN PEMBAHASAN}

Berdasarkan hasil temuan yang dilakukan melalui observasi, wawancara dan dokumentasi proses pengembangan kecerdasan spiritual di SD Plus Nurul Hikmah Pamekasan dan MIN Konang Pamekasan sebagai berikut :

Di SD Plus Nurul Hikmah dan MIN Konang startegi guru dalam mengajarkan pembelajaran PAI guna dalam mengembangkan kecerdasan spiritual yaitu guru di kedua sekolahan tersebut berusaha menciptakan suasana pembelajaran yang mengandung unsur nilai-nilai spiritual, maka dalam pembelajaran guru harus meningkatkan kesadaran yaitu pendidikan di kelas berjalan sebagaimana tema-tema yang ditentukan dalam rencana pembelajaran, rasa kebermaknaan yaitu peserta didik merasa bahwa materi dalam pembelajaran penting bagi mereka, evaluasi dalam pembelajaran, pembelajaran yang bermakna yang terkait dengan pengalaman pribadi peserta didik, visi dalam pembelajaran, pengembangan kemampuan siswa 
dalam hal spiritualitas di masa depan yang dilakukan secara bertahap dan misi yaitu tujuan utama yang harus diwujudkan dalam bentuk yang nyata.

Menurut Richard A. Bowell (London Necholas Brealey :37) dalam bukunya yang berjudul The Seven Step of Spiritual Intelligence: The Pratical Pursuit of Purpose, Success and Happiness Langkah-langkah dalam membangun kecerdasan spiritual dalam pembelajaran ada tujuh langkah dalam membangun kecerdasan spiritual yaitu : 1) Kesadaran, Pentingnya guru untuk mengajak peserta didik ke dalam dimensi spiritual yaitu tentang pentingnya materi yang hendak diberikan dan membuat peserta didik menyadari akan pentingnya materi yang diajarkan bagi diri peserta didik, 2) Kebermaknaan, memberikan makna di balik materi yang bermanfaat untuk diri peserta didik, 3) Evaluasi, nalar siswa yang tinggi terkadang mengakibatkan suatu pemahaman yang diluar materi, oleh karena itu hendaknya guru memberikan arahan, bimbingan dan koreksi, 4) menciptakan suasana belajar yang bermakna yaitu mengaitkan pembelajaran dengan pengalaman pribadi peserta didik, 5) Visi, cita-cita peserta didik merupakan pendorong utama tumbuhnya spiritualitas. 6) Proyeksi, upaya untuk melakukan suatu perubahan secara bertahap yang berhubungan dengan kemampuan peserta didik dalam hal spiritualitas di masa depan. 7) Misi, untuk mengembangkan kecerdasan spiritual pada diri peserta didik merupakan tujuan utama yang harus diwujudkan dalam bentuk kegiatan nyata. Ketujuh langkah tersebut merupakan elemen penting dalam mengembangkan kecerdasan spiritual yang tertanam dalam pembelajaran, pembangunan kesadaran dari dalam dan di dalam pembelajaran merupakan kunci utama sebagai tahap pembentukan kecerdasan spiritual pada peserta didik.

Proses pengembangan kecerdasan spiritual di SD Plus Nurul Hikmah dimulai dari guru mengajarkan kepada anak berdasarkan materi pembelajaran yang ada didalam pembelajaran PAI, hal ini bertujuan agar anak mengetahui nilai-nilai islam. Materi tentang rukun iman dan rukun islam dalam pembelajaran PAI benar-benar ditanamkan, rukun iman yang terdiri dari beriman kepada Allah, iman kepada malaikat, iman kepada kitab-kitab Allah, iman kepada rasul, iman kepada hari akhir dan iman kepada qadha dan dan qadar serta rukun islam yang terdiri dari syahadat, shalat, puasa, zakat dan haji yang nilai-nilai tersebut kemudian diaplikasikan dalam kegiatan keagamaan yang nyata.

Ary Ginanjar Agustian dalam bukunya ESQ (Emotional Spiritual Quetiont) menyebutkan dalam membentuk kecerdasan spiritual harus berpedoman pada nilainilai rukun iman dan rukun islam yang merumuskan ihsan, rukun iman dan rukun islam dengan "ESQ way 165". simbol 165 merupakan penjabaran dari 1 ihsan, 6 rukun iman dan 5 rukun islam sebagai berikut :1). Prinsip Bintang ( Beriman Kepada Allah), 2) Prinsip Malaikat (Iman kepada Malaikat), 3) Prinsip iman kepada kitab- 


\section{Pengembangan Kecerdasan Spiritual}

kitab Allah, 4) Prinsip iman kepada rasul Allah, 5) Prinsip visi ke depan ( Iman Kepada Hari Akhir) dan 6) Prinsip iman kepada Qadha dan Qadar.11

Sedangkan di MIN Konang Galis Strategi guru dalam Proses pengembangan kecerdasan spiritual di dalam pembelajaran dilakukan dengan cara Penanaman sifatsifat rasul dan peneladanan kisah rasul dalam pembelajaran PAI, dalam mata pelajaran aqidah akhlak dijelaskan tentang materi mengenal sifat-sifat wajib nabi dan rasul yang harus dicontoh oleh peserta didik dan diterapkannya baik disekolah maupun di rumah, materi tersebut dijelaskan secara berjenjang berdasarkan tingkat kelas masing-masing kemudian penjelasan kisah-kisah rasul dijelaskan pada mata pelajaran SKI (Sejarah Kebudayaan Islam).

Berdasarkan hasil temuan di atas, hal ini senada dengan teori yang diungkapkan oleh teori Al-Ghazali tentang konsep pendidikan yang dikutip oleh Jalaludin Rahmat dalam bukunya "Mengembangkan kecerdasan spiritual anak sejak dini",12 bahwa Metode atau cara yang bisa diterapkan oleh guru dalam rangka proses pembentukan kecerdasan spiritual siswa dan melalui aktivitas kegamaan menurut menurut Jalaludin Rakhmat sebagai berikut: Pertama, menjadi seorang yang mengembangkan nilai spiritual yaitu seorang pendidik harusmenggali dan memperdalam wawasan tentang nilai-nilai spiritual. Pengkondisian diri sebagai seorang yang selalu ingin menguatkan spiritualitasnya akan menjadi kekuatan internal untuk menarik perhatian anak mengikuti arahan dan bimbingan pendidik. Kedua, seorang anak harus sudah dibiasakan untuk memaknai setiap tindakannya dengan memahamkan apa dan tujuannya dalam mengambil suatu pilihan tindakan, sehingga langkahnya jelas karena ada tujuan dan makna yang ingin dicapai (vissioner). Misalnya tujuan anak untuk sekolah, apa yang ingin diraih setelah melakukan suatu kegiatan, termasuk apa yang ingin dicapai dalam kehidupan ke depan (cita-cita dan tujuannya). Ketiga, dalam pendidikan agama Islam pengenalan dan latihan membaca kitab suci al-Quran merupakan materi utama yang harus dikuasai anak. Keempat, anak pada umumnya senang mendengarkan cerita terutama anak dalam usia pra-sekolah hingga usia sekolah dasar. Menceritakan kisah-kisah teladan yang mengandung nilai spiritualitas akan membantu anak memahami nilainilai kehidupan. Kelima, membiasakan membahas dan mendiskusikan persoalan dengan anak secara rasional akan melatih anak berpikir logis dan obyektif. Jika dikuatkan dengan perspektif ruhaniyah akan membangkitkan sisi spiritual anak untuk membantunya membangun mental yang sehat dan seimbang antara pemahaman rasional dan spiritualnya. Keenam, melibatkan anak dalam kegiatankegiatan ritual keagamaan dapat dijadikan sebagai kegiatan pembiasaan dan

\footnotetext{
${ }^{11}$ Ary Ginanjar Agustian, Rahasia Sukses Membangun Kecerdasan Emosi dan Spiritual ESQ Berdasarkan 6 Rukun Iman dan 5 Rukun Islam. (Jakarta : CV. Pustaka Abadi, 2002) hlm. 56

12 Jalaludin Rahmat, Mengembangakn Kecerdsan Spiritual Anak Sejak Dini (Bandung: Mizan, 2007), hlm. 68
} 
pelatihan mental untuk memiliki ikatan dengan Allah swt. Misalnya mengajak shalat berjamaah, mengajak anak menjalankan ibadah puasa baik wajib maupun sunnah, membagikan zakat, dan bersama membaca al-Quran, bahkan memberi kepercayaan kepada anak untuk memimpin doa setelah shalat. Ketujuh, tegaskan pada anak bahwa keikutsertaannya dalam kegiatan sosial bukan untuk dilihat atau dipuji. Akan tetapi sebagai bentuk kepedulian dan kepekaan sosial yang hal itu sudah merupakan kewajiban dan kebutuhan rasa sosial setiap manusia.

Sedangkan pelaksanaanya bahwa Selain guru menanamkan nilai-nilai ajaran agama islam dan nilai karakter dalam pembelajaran, guru di SD Plus Nurul Hikmah dan MIN Konang Galis juga memberi motivasi agar peserta didik dapat menerapkan nilai-nilai ajaran agama islam dan nilai karakter kedalam bentuk kegiatan dan tingkah laku sehari-hari sehingga ilmu yang diperoleh peserta didik tidak sia-sia dan mereka juga mendapat pahala jika mampu menerapkannya serta menunjukkan bahwa guru berhasil dalam menyampaikan materi pelajaran serta nasehat ke peserta didik dan dapat disimpulkan bahwa guru berhasil mengembangkan kecerdasan spiritual pada peserta didik, karena peserta didik yang cerdas spiritualnya akan menjalani hidupnya sesuai dengan nilai-nilai ajaran islam yang diajarkan disekolah yang kemudian bisa diterapkan dalam kegiatan dan tingkah laku sehari.

Khalil Khavari, dalam bukunya ciri-ciri kecerdasan spiritual dalam diri manusia, ${ }^{13}$ menyatakan bahwa Kecerdasan spiritual bisa diartikan sebagai merohanikan diri, yaitu berarti kecerdasan spiritual bukan hanya sekedar imajinasi atau angan-angan,tapi merupakan pengalaman nyata bagi orang-orang yang benarbenar merasakan dan mengalami sendiri dengan diwujudkannya dalam bentuk kegiatan agama yang bertujuan untuk memahami kebenaran-kebenaran hakiki yang terkait dengan iman dan taqwa pada Tuhan Yang Maha Esa.

Penemuan penelitian mengenai dampak pengembangan kecerdasan spiritual pada peserta didik di SD Plus Nurul Hikmah Pamekasan dan MIN Konang Galis Pamekasan dapat dilihat dari tingkah laku peserta didik, yaitudilihat dari sudut pandang relasi vertikal, hubungan dengan yang Maha Kuasa). Sudut pandang ini akan melihat sejauh manakah tingkat relasi spritual peserta didik dengan Sang Pencipta, yang diterapakan oleh peserta didik dalam bentuk kegiatan keagamaan seperti berdoa sebelum pelajaran untuk meminta ilmu yang barokah, mengaji, ibadah shalat, berdzikir dan membaca Asmaul Husna, selain itu juga dilihat dari sudut pandang relasi sosial-keagamaan. dalam sudut pandang ini Kecerdasan spiritual akan tercermin dari tingkah laku peserta didik yang peduli kepada temannya dan menganggap hubungan antar temannya itu adalah sebuah hubungan kekeluargaan, yang ditunjukkan melalui sikap, tolong menolong, dermawan kepada temannya.

Menurut Kavari dalam bukunya Ciri-ciri kecerdasan spiritual dalam diri manusia, ${ }^{14}$ yang mengatakan bahwa terdapat tiga bagian yang dapat kita lihat untuk

\footnotetext{
${ }^{13}$ Khalil Khavari, Ciri-ciri Kecerdasan Spiritual dalam Diri Manusia.(Bandung: Mizan, 2005), hlm. 65

${ }^{14}$ Ibid, Khalil Kavari, hlm. 89
}

171 MODELING, Volume 6, Nomor 2, September 2019 


\section{Pengembangan Kecerdasan Spiritual}

menguji tingkat kecerdasan spritual Peserta didik yaitu dilihat dari: 1. Sudut pandang relasi vertikal, hubungan dengan yang Maha Kuasa). Sudut pandang ini akan melihat sejauh manakah tingkat relasi spritual kita dengan Sang Pencipta, Hal ini dapat diukur dari "segi komunikasi dan intensitas spritual individu dengan Tuhannya”. Menifestasinya dapat terlihat dari pada frekwensi do'a, makhluq spritual, kecintaan kepada Tuhan yang bersemayam dalam hati, dan rasa syukur kehadiratNya. 2. Sudut pandang relasi sosial-keagamaan. Sudut pandang ini melihat konsekwensi psikologis spritual-keagamaan terhadap sikap sosial yang menekankan segi kebersamaan dan kesejahteraan sosial.

\section{PENUTUP}

Berdasarkan beberapa temuan dalam penelitian yang telah diuraikan, terlihat bahwa di SD Plus Nurul Hikmah Pamekasan proses pengembangan kecerdasan dilakukan dengan cara penanaman nilai rukun iman yang diantaranya beriman kepada Allah dengan cara membaca al-Qur'an karena dengan membaca al-Qur'an mempunyai tujuan agar membersihkan akal dan menyucikan jiwa dari segala bentuk syirik serta menetapkan keyakinan tentang ke-esa-an yang sempurna bagi Tuhan seru sekalian alam dan rukun Islam yang diantaranya sholat karena dengan sholat maka pikiran, raga dan batin seseorang akan terasa tenang, sejuk dan damai karena mengingat Allah setelah melakukan aktivitas penuh pada pagi hari. dan juga penanaman karakter religius, jujur dan tanggung jawab.

Sedangkan di MIN Konang Galis Pamekasan proses pengembangan kecerdasan spiritual dalam pembelajaran dilakukan dengan cara Penanaman sifat-sifat rasul yang diantaranya amanah yang artinya dapat dipercaya contoh pelaksanaannya pada peserta didik yaitu dilakukan dengan cara melaksanakan segala kegiatan yang ada disekolah dengan penuh tanggung jawab terhadap apa yang menjadi kewajiban dan tugasnya disekolah dan penanaman karakter seperti sopan, santun, religius dan disiplin.

Adapun pelaksanaanya, di SD Plus Nurul Hikmah menerapkan nilai-nilai rukun iman dan rukun islam dalam bentuk kegiatan di sekolah dan penerapan karakter yang baik di sekolah dan di rumah, Pelaksanaan aktivitas keagamaan di sekolah dan di rumah, Pengawasan pihak sekolah dan orang tua dalam pembentukan kecerdasan spiritual, pengawasan pihak sekolah: Bagian kurikulum bertugas untuk mengontrol jalannya pembelajaran di kelas, perilaku atau sikap serta aktivitas keagamaan di sekolah di kontrol oleh wali kelas dan kepala sekolah bertugas untuk membuat dan mengisi instrument monitoring yang terdiri dari perencanaan, pelaksanaan kegiatan Aktivitas keagamaan dan juga hasil dari pelaksanaan program. Sedangkanpengawasandi rumahdilakukan oleh orang tua, jika tidak bisa akan diwakilkan dengan keluarga yang ada di rumah.

Sedangkan di MIN Konang Galis Pamekasan yaitu: Pelaksanaan perilaku terpuji yang berdasarkan tauladan dari sifat-sifat nabi dan penerapan karakter di sekolah dan di rumah, Pelaksanaan aktivitas keagamaan di sekolah dan di rumah, 
Pengawasan pihak sekolah dan orang tua dalam pembentukan kecerdasan spiritual, pengawasan pihak sekolah: Waka kurikulum dan wali kelas bertugas untuk mengamati dan menilai setiap jalannya pembelajaran di kelas sedangkan wali kelas, kaur kesiswaan dan guru yang lain bertugas untuk mengamati jalannya program keagamaan, sedangkan pengawasan di rumah dilakukan oleh orang tua atau pihak keluarga.

Dampak pengembangan kecerdasan spiritual melalui aktivitas keagamaan di SD Plus Nurul Hikmah Pamekasan, sebagai berikut; 1) Mempunyai sifat disiplin, 2) Mempunyai sifat kejujuran, 3) Tingkat pergaulan kesesama peserta didik baik, 4) Sopan dan santun kepada guru dan orang tua, 5) Tanggung jawab dan Termotivasi menanamkan hal yang baik dari dirinya sendiri. Sedangkan dampak pembentukan kecerdasan spiritual melalui aktivitas keagamaan di rumah sebagai berikut; Peserta didik selama di rumah konsisten dalam mengerjakan ibadah sholat, mengaji, berpuasa penuh bagi yang sudah baligh, mengerjakan pekerjaan rumah, mengerjakan PR di rumah dan rajin membantu orang tua serta patuh kepada perintah orang tua.

Dampak pengembangan kecerdasan spiritual melalui aktivitas keagamaan di MIN Konang, sebagai berikut; Rasa keimanan dan ketakwaan kepada Allah swt semakin meningkat, mempunyai sifat sopan, santun dan ramah, mempunyai sifat disiplin dan menghargai waktu serta memiliki rasa tanggung jawab, memiliki rasa empati dan tolong menolong, mempunyai sifat kejujuran dan rendah hati, peserta didik dapat membagi waktunya. Sedangkan dampak di rumah; Mempunyai sikap Sopan, santun dan ramah, Keimanan dan ketakwaan peserta didik meningkat, Mempunyai sikap disiplin dan rasa tanggung jawab dan Mempunyai sikap tolong menolong.

\section{DAFTAR PUSTAKA}

Abd Mujib, Muhaimin. 1993. Pemikiran Pendidikan Islam: Kajian Filosofis dan Kerangka Dasar Operasionalnya. Bandung : Trigenda Karya.

Adiningsih, Jurnal pendidikan, http://www.pikiranrakyat.com/15/0801.html).

Adisusilo, Sutarjo. 2014. Pembelajaran Nilai-nilai Karakter. Jakarta: Raja Grafindo Persada.

Agustian, Ginanjar, Ary. 2002. Rahasia Sukses Membangun Kecerdasan Emosi dan Spiritual ESQ Berdasarkan 6 Rukun Iman dan 5 Rukun Islam. Jakarta: CV. Pustaka Abadi.

Amalia, Rina. Kerjasama Guru dan Orang Tua Siswa dalam Membentuk Insani Yang Berakhlak Mulia melalui Pendidikan Agama Islam di SDI Plus Semen Palu. Jurnal El Harakah vol. 18, no 1 tahun 2016.

Amin, Moh. dkk. 2000. Modul Quran Hadits I. Jakarta: Direktorat Jendral Pembinaan Kelembagaan Agama Islam.

Badan Pusat Statistik, http://www.tribunjabar.co.id/read/artikel. 
Bogdan, R.C.\& Biklen, S.K. 1998. Qualitatitive Research for Education an Introduction to Theory and Methods. London: Allyn\&Bacon, Inc.

Daradjat, Zakiyah. 2012. Ilmu Pendidikan Islam. Jakarta : Bumi Aksara.

Dita, Rahayu. Artikel, Krisis Moral , 2015.http://www.kompasiana.

Emmons , A, Roberts. 2005. The Psychology of Ultimate Concerns . Terj. Juita. Bandung: Mizan.

Fadloli. 2011. Pendidikan Agama Islam. Malang : Aditya Medika Publishing.

Faisal, Sanapiah. 1990. Penelitian Kualitatif Dasar-Dasar Dan Aplikasi. Malang: Yayasan Asih Asuh Malang.

Kavari, Khalil 2005. Ciri-ciri Kecerdasan Spiritual dalam Diri Manusia. Bandung: Mizan.

Lexy Moleong. 2006. Metodology Penelitian Kualitatif. Bandung: PT Remaja Rosdakarya.

M. Mulyono, Anton. 2001. Aktivitas Belajar di Sekolah. Surabaya: Pustaka Media.

Marshall, Ian. dan Zohar, Danah. 2005. Spiritual Capital : Memberdayakan SC di Dunia Bisnis, Terj. Helmi Mustofa. Bandung: Mizan.

Moleong, Lexy. 2006. Metodology Penelitian Kualitatif. Bandung: PT Remaja Rosdakarya.

Mubarok, Achmad. 2002. Konseling Agama, Teori dan Kasus. Jakarta: PT Bina Rena Pariwara.

Muhaimin. 2005. Pengembangan Kurikulum Pendidikan Agama Islam. Jakarta: PT Raja Grafindo Persada.

Muhaimin. 2009. Rekontruksi Pendidikan Islam. Jakarta : Rajawali Press.

Muthahhari, Rahmat. or.id/doc/artikel/sqanak.htm).http://www.kompasiana.com.

Nasr, Hossein, Sayyed. 1989. Antara Tuhan dan Manusia. Jakarta: Rajawali Pers.

Nata, Abudin. 2012. Metodologi Studi Islam. Jakarta : PT. Raja Grafindo Persada.

Poerwadarminta, W.J.S. 1998. Pengantar Ilmu Jiwa Agama. Jakarta: Kalam Mulia.

Poerwadarminto. 1984. Kamus Bahasa Indonesia. Jakarta: Balai pustaka.

Rahmat, Jalaludin. 2007. Mengembangakn Kecerdsan Spiritual Anak Sejak Dini. Bandung : Mizan.

Ramayulis,. 1990. Metodologi Pendidikan Agama Islam. Jakarta: Radar Jaya Offset.

Ramayulis. 2008. Metodologi Pendidikan Agama Islam. Jakarta: Kalam Mulia.

Robert K. Yin.Case Study Research Design and Methods. London: Sege Publication.

Rosalia. 2005. Segala Bentuk Aktivitas Belajar Siswa. Bandung : Ar-Ruzz Media.

Ruslan. 2005. Menyingkap Rahasia Spiritualitas. Makasar : Al-Zakaria.

Salim, Peter. 2000. Salim's Ninth Collegiate English-Indonesian Dictionary. Jakarta: Modern English Press.

Sinetar, Marsha. 2001. Spiritual Intelligence Kecerdasan Spiritual, Terj. Soesanto Boedidarmo . Jakarta: PT. Elex Media Komputindo.

Sinetar. 2009. Faktor-faktor yang Mempengaruhi Kecerdasan Spiritual. Jakarta: PT. AlMawardi Prima.

Siswanto, Wahyudi. 2010. Membentuk Kecerdasan Spiritual Anak. Jakarta : Amzah. 
Sukmadinata, Syaodih, Nana. 2010. Metode Penelitian Pendidikan. Bandung: PT Remaja Rosdakarya.

Sulaiman, Hasan, Fathiyah. 1999. Konsep Pendidikan al-Ghazali. Jakarta : P3M.

Syah, Muhibbin. 2003. Psikologi Pendidikan Islam. Bandung : Remaja Rosdakarya.

175 | MODELING, Volume 6, Nomor 2, September 2019 